\title{
The Improvement of the Quality of Irrigation Water Contaminated with Heavy Metals in the Borg El Arab, Egypt
}

\author{
Mohamed Kamel Fattah' ${ }^{1}$, S. A. E. Abdelrazek ${ }^{2}$ \\ ${ }^{1}$ Environmental Studies and Researches Institute, Sadat City University, Sadat, Egypt \\ ${ }^{2}$ Soil, Water and Environment Research Institute, Agriculture Research Center, Cairo, Egypt \\ Email: kamelhydro90@yahoo.com
}

Received 7 October 2014; revised 7 November 2014; accepted 25 November 2014

Copyright @ 2014 by authors and Scientific Research Publishing Inc.

This work is licensed under the Creative Commons Attribution International License (CC BY). http://creativecommons.org/licenses/by/4.0/

(c) (7) Open Access

\begin{abstract}
The aim of this study is to estimate the effects of the accumulation of harmful heavy metals in the irrigation water resulting from the proximity of the various activities of various water: sewage, artesian wells and industrial activities, particularly Borg El Arab Industrial area and take Nile water 1 Control (Bahig canal). The concentrations of these heavy metals in samples drawn from different distances from the source of irrigation in summer 2011 that contain the highest concentrations, followed by the winter of 2012. These results have shown that the amount of heavy metals in the samples at a distance of 50 meters is more than quantity of $5000 \mathrm{~m}$ by a 30 to 35 twice in water for irrigation, also the amount of heavy metals in the samples at a distance of $\mathbf{5 0}$ meters has values less than the permissible limits and disappeares completely at a distance of 5000 meters and that for different sources.
\end{abstract}

\section{Keywords}

Artificial Water, Sludge Water, Pollution, Heavy Metals, Water Quality Improving

\section{Introduction}

Survey study was carried out an area located at the satellite of Burg El-Arab. The studied area constitutes a part of the eastern section of the north-western coastal of A.R.E $48 \mathrm{~km}$, and west of Alexandria-Marsa Matroh road it lies approximately between latitudes $30^{\circ} 45^{\prime} \mathrm{N}$ and $30^{\circ} 55^{\prime} \mathrm{N}$ and longitudes $29^{\circ} 30^{\prime} \mathrm{E}$ and $29^{\circ} 50^{\prime} \mathrm{E}$, The study area covers the total area 5000 fed dens map. The area shows many differences in elevation and relief the elevation varies between zero and more than $40 \mathrm{M}$ above sea level. The hydrochemical study reveals the quality of water 
that is suitable for drinking, agriculture and industrial purposes and helps in understanding the change in quality due to rock-water interaction or any type of anthropogenic influence. The rapid extension of industrial developed countries was accompanied by many problems of pollution especially due to wastewater discharged from factories. Heavy metals produced by different industrial processes are the most harmful pollutes in these wastes [1].

In general, wastewater could be divided into water as the bulk volume and three other categories included: suspended solids, colloidal materials, and dissolved materials. [2] showed that the potential problems due to the use of wastewater on cropland include ground and surface water contamination, pathogens, odors, and heavy metals entry into the food chain that industrial liquid wastes are more various and more concentrated and contain certain various acids, alkalis chemical contaminants oil, coarse, solids, and other constituents. The dissolved nutrients (phosphate, ammonium, nitrate, potassium, sodium, calcium, sulfates, etc). toxic wastes heavy metals are mostly from industry; $\mathrm{Cu}, \mathrm{Zn}, \mathrm{Hg}, \mathrm{Pb}, \mathrm{Cd}, \mathrm{Cr}$, Co, As etc.) and non biodegradable organic chemicals variation of groundwater quality in an area is a function of physical and chemical parameters that are greatly influenced by geological formations and anthropogenic activities [3].

In Egypt, many investigators warned of the residual effects of factories pollution of the biosphere [4].

\section{Material and Methods}

In winter 2012, the Investors Union in Burg El-arab area has been treated the Artificial water before mixing with Nile water and the same with Sludge water in mary mina station with E-JUST Japans Tokyo Technology, (E-JUST, Tokyo Institute of Technology, Report in heavy metals and salts treatment in Burg-El-Arab area 2012) The objective of this work was to investigate the contamination of water in the vicinity of factories region of Burg El-Arab by heavy metals and improving the quality of this irrigation water. Cetro-Cal compound from AGRI-CO reduced salinity and heavy metals in artesian water. Agricultural area around Burg-El Arab Artificial water, sludge water, artesian water and Nile water were selected for the current study (Figure 1).

In July 2011 and January 2012, samples of irrigation water samples were carried according to standard methods [5]. Total soluble salts pH by pH meter and EC according to [6] Table 1. The analysis chemical properties of the non polluted water (Bahig Canals) at (50 - $5000 \mathrm{~m}$ ) and Polluted water (Artificial water, sludge water, artesian water) at (50 - $5000 \mathrm{~m}$ ). The concentration of $\mathrm{Fe}, \mathrm{Cu}, \mathrm{Zn}, \mathrm{Mn}, \mathrm{Pb}, \mathrm{Cd}$, Co and $\mathrm{Ni}$ were determined by atomic absorption spectrophotometer Model 238 Perkin-Elme [7], BOD (biochemical oxygen demand) [8]-[11].

\section{Results and Discussion}

\subsection{Major Ions Distribution}

The results of chemical analyses of the collected water samples (Table 1) showed that, (Bahig (fresh water) calcium is the most dominant cation followed by sodium and magnesium $\left(\mathrm{Ca}^{2+}>\mathrm{Na}^{+}>\mathrm{Mg}^{2+}\right)$. These elements show wide range of chemical concentration, calcium concentration ranges from 68 to $36 \mathrm{mg} / \mathrm{l}$, sodium concentration ranges from 27 to $23 \mathrm{mg} / \mathrm{l}$, and magnesium concentration ranges from 18 to $14 \mathrm{mg} / \mathrm{l}$. Low concentrations represent low water salinity dominated at the Bahig area.

El-Rawaisate (artesian water), sodium is the most dominant cation followed by calcium and magnesium and $\left(\mathrm{Na}^{+}>\mathrm{Ca}^{2+}>\mathrm{Mg}^{2+}\right)$. These elements show wide range of chemical concentration, sodium concentration ranges from 136 to $134 \mathrm{mg} / \mathrm{l}$, calcium concentration ranges from 102 to $98 \mathrm{mg} / \mathrm{l}$, and magnesium concentration ranges from 22 to $27 \mathrm{mg} / \mathrm{l}$. Low concentrations represent low water salinity dominated at the El-Rawaisate area.

Mary Mina (sewage water), sodium is the most dominant cation followed by magnesium and calcium $\left(\mathrm{Na}^{+}>\right.$ $\mathrm{Mg}^{2+}>\mathrm{Ca}^{2+}$ ), These elements show relatively high values of chemical concentration, sodium concentration ranges from 301 to $439 \mathrm{mg} / \mathrm{l}$, calcium concentration ranges from 156 to $148 \mathrm{mg} / \mathrm{l}$, and magnesium concentration ranges from 88 to $99 \mathrm{mg} / \mathrm{l}$. high concentrations represent high water salinity dominated at Mary Mina area. While some groundwater samples show increasing of calcium over magnesium $\left(\mathrm{Na}^{+}>\mathrm{Ca}^{2+}>\mathrm{Mg}^{2+}\right)$ as a result of cation exchange processes

Burg-El-Arab Industrial Zone (artificial water), sodium is the most dominant cation followed by magnesium and calcium $\left(\mathrm{Na}^{+}>\mathrm{Mg}^{2+}>\mathrm{Ca}^{2+}\right)$, These elements show relatively high values of chemical concentration, sodium concentration ranges from 441 to $382 \mathrm{mg} / \mathrm{l}$, calcium concentration ranges from 150 to $144 \mathrm{mg} / \mathrm{l}$, and magnesium concentration ranges from 86 to $73 \mathrm{mg} / \mathrm{l}$. high concentrations represent high water salinity dominated at 
Table 1. Chemical properties of irrigation water of BAHIG area (Nile water) and BURG-EL ARAB area (Artesian, Sludge and Artificial water).

\begin{tabular}{|c|c|c|c|c|c|c|c|c|c|c|c|c|}
\hline \multirow{2}{*}{$\begin{array}{l}\text { Distance } \\
\text { (m) }\end{array}$} & \multirow{2}{*}{ Seasons } & \multirow{2}{*}{$\mathrm{pH}$} & \multirow{2}{*}{$\begin{array}{c}\text { E.C } \\
\mathrm{dS} \cdot \mathrm{m}^{-1}\end{array}$} & \multirow[b]{2}{*}{$\mathrm{Na}$} & \multicolumn{2}{|c|}{ Cation epm } & \multirow[b]{2}{*}{$\mathrm{Mg}^{2}$} & \multicolumn{3}{|c|}{ Anion epm } & \multirow{2}{*}{ SAR } & \multirow{2}{*}{$\begin{array}{l}\text { Quality } \\
\text { classes }\end{array}$} \\
\hline & & & & & $\mathrm{K}$ & $\mathrm{Ca}^{2}$ & & $\mathrm{HCO}_{3}$ & $\mathrm{Cl}$ & $\mathrm{SO}_{4}^{2-}$ & & \\
\hline \multicolumn{13}{|c|}{ Nile water } \\
\hline \multirow{2}{*}{50} & $\mathrm{~S}$ & 7.9 & 0.81 & 1.19 & 0.13 & 3.40 & 1.5 & 2.81 & 2.91 & 0.50 & 0.76 & C2-S1 \\
\hline & $\mathrm{W}$ & 7.6 & 0.78 & 1.11 & 0.08 & 2.90 & 1.2 & 2.16 & 2.81 & 0.32 & 0.75 & C2-S1 \\
\hline \multirow{2}{*}{250} & $\mathrm{~S}$ & 7.8 & 0.66 & 1.28 & 0.12 & 2.25 & 1.2 & 2.65 & 1.72 & 0.48 & 0.98 & C2-S1 \\
\hline & $\mathrm{W}$ & 7.5 & 0.61 & 1.12 & 0.09 & 2.12 & 1.1 & 2.42 & 1.61 & 0.40 & 0.89 & $\mathrm{C} 2-\mathrm{S} 1$ \\
\hline \multirow{2}{*}{500} & $\mathrm{~S}$ & 7.9 & 0.91 & 1.23 & 0.14 & 2.15 & 1.2 & 2.31 & 1.81 & 0.60 & 0.95 & C2-S1 \\
\hline & $\mathrm{W}$ & 7.4 & 0.89 & 1.05 & 0.11 & 2.11 & 0.9 & 1.95 & 1.72 & 0.50 & 0.86 & $\mathrm{C} 2-\mathrm{S} 1$ \\
\hline \multirow{2}{*}{1000} & $\mathrm{~S}$ & 7.8 & 0.66 & 1.52 & 0.21 & 1.52 & 1.5 & 2.81 & 1.42 & 0.52 & 1.24 & C2-S2 \\
\hline & $\mathrm{W}$ & 7.3 & 0.61 & 1.31 & 0.13 & 1.31 & 1.3 & 2.25 & 1.32 & 0.48 & 1.15 & C2-S2 \\
\hline \multirow{2}{*}{1500} & $\mathrm{~S}$ & 7.7 & 0.72 & 1.45 & 0.23 & 2.77 & 1.5 & 2.61 & 2.88 & 0.46 & 0.99 & C2-S1 \\
\hline & W & 7.4 & 0.62 & 1.21 & 0.11 & 1.99 & 1.4 & 1.64 & 2.70 & 0.37 & 0.93 & C2-S1 \\
\hline \multirow{2}{*}{5000} & $\mathrm{~S}$ & 7.5 & 0.69 & 1.24 & 0.29 & 1.82 & 1.6 & 2.62 & 1.91 & 0.45 & 1.04 & C2-S2 \\
\hline & $\mathrm{W}$ & 7.2 & 0.63 & 1.01 & 0.21 & 1.09 & 1.2 & 1.53 & 1.67 & 0.31 & 0.94 & C2-S1 \\
\hline \multicolumn{13}{|c|}{ Artesian water } \\
\hline \multirow{2}{*}{50} & $\mathrm{~S}$ & 8.8 & 2.53 & 7.1 & 0.15 & 5.12 & 1.9 & 5.94 & 5.91 & 2.42 & 3.80 & C3-S3 \\
\hline & $\mathrm{W}$ & 8.2 & 1.96 & 6.35 & 0.06 & 4.99 & 1.4 & 4.47 & 5.42 & 1.91 & 3.55 & C3-S4 \\
\hline \multirow{2}{*}{250} & $\mathrm{~S}$ & 8.5 & 2.92 & 9.5 & 0.29 & 7.84 & 3.8 & 2.50 & 14.9 & 4.03 & 3.86 & C3-S3 \\
\hline & W & 7.9 & 1.82 & 7.24 & 0.09 & 7.15 & 2.9 & 1.57 & 12.81 & 3.00 & 3.19 & C3-S4 \\
\hline \multirow{2}{*}{500} & $\mathrm{~S}$ & 8.4 & 2.71 & 9.66 & 0.19 & 9.89 & 2.6 & 5.30 & 12.12 & 4.92 & 3.86 & C3-S3 \\
\hline & W & 7.9 & 1.61 & 8.15 & 0.11 & 8.96 & 2.0 & 4.98 & 10.33 & 3.91 & 3.48 & C3-S4 \\
\hline \multirow{2}{*}{1000} & $\mathrm{~S}$ & 8.3 & 2.34 & 10.5 & 0.21 & 7.91 & 3.9 & 5.10 & 13.21 & 4.21 & 4.32 & C3-S4 \\
\hline & W & 7.8 & 1.72 & 8.41 & 0.09 & 7.82 & 2.8 & 3.93 & 11.51 & 3.68 & 3.68 & C3-S4 \\
\hline 1500 & $\mathrm{~S}$ & 8.3 & 2.42 & 7.67 & 0.12 & 4.92 & 1.8 & 4.90 & 5.10 & 4.51 & 8.02 & C3-S4 \\
\hline & W & 8.0 & 1.36 & 9.92 & 0.08 & 4.81 & 1.1 & 4.65 & 9.35 & 1.91 & 5.77 & C3-S4 \\
\hline 5000 & $\mathrm{~S}$ & 8.2 & 2.31 & 7.10 & 0.13 & 4.91 & 2.3 & 5.80 & 6.20 & 2.44 & 3.76 & C3-S3 \\
\hline 8000 & W & 8.0 & 1.14 & 6.09 & 0.07 & 3.96 & 1.9 & 3.69 & 6.12 & 2.21 & 3.56 & $\mathrm{C} 2-\mathrm{S} 4$ \\
\hline & & & & & & ge wat & & & & & & \\
\hline 50 & $\mathrm{~S}$ & 7.3 & 3.80 & 13.10 & 0.31 & 7.81 & 7.3 & 4.32 & 14.9 & 9.30 & 4.76 & C4-S4 \\
\hline & W & 7.1 & 3.72 & 12.81 & 0.21 & 6.71 & 6.9 & 3.91 & 13.82 & 8.90 & 4.91 & C4-S4 \\
\hline 250 & $\mathrm{~S}$ & 7.3 & 3.70 & 17.00 & 0.25 & 6.29 & 7.1 & 2.12 & 27.49 & 1.10 & 6.56 & C4-S4 \\
\hline & W & 7.0 & 3.69 & 14.12 & 0.12 & 6.11 & 6.8 & 1.94 & 24.30 & 1.00 & 5.59 & C4-S4 \\
\hline 500 & $\mathrm{~S}$ & 6.8 & 3.70 & 18.17 & 0.29 & 7.08 & 7.1 & 4.47 & 24.67 & 3.50 & 6.83 & C3-S4 \\
\hline & W & 6.2 & 3.61 & 16.98 & 0.15 & 6.92 & 6.9 & 3.62 & 23.91 & 3.42 & 6.49 & C4-S4 \\
\hline 1000 & $\mathrm{~S}$ & 6.5 & 3.5 & 19.00 & 0.25 & 7.36 & 6.3 & 4.21 & 28.00 & 0.70 & 7.28 & C3-S4 \\
\hline & W & 6.2 & 3.31 & 18.28 & 0.12 & 6.31 & 6.0 & 3.91 & 26.29 & 0.51 & 7.37 & C3-S4 \\
\hline & $\mathrm{S}$ & 7.2 & 3.5 & 19.0 & 0.28 & 7.40 & 6.9 & 4.79 & 28.60 & 2.19 & 7.12 & C4-S4 \\
\hline 1000 & W & 6.9 & 3.36 & 18.91 & 0.19 & 6.31 & 6.2 & 3.82 & 26.58 & 1.21 & 7.56 & C3-S4 \\
\hline & $\mathrm{S}$ & 6.9 & 3.60 & 19.0 & 0.25 & 7.41 & 8.3 & 3.21 & 27.80 & 3.95 & 6.79 & C4-S4 \\
\hline & W & 6.5 & 3.27 & 18.82 & 0.18 & 6.36 & 6.9 & 3.38 & 25.90 & 2.98 & 7.29 & C3-S4 \\
\hline
\end{tabular}




\section{Continued}

\begin{tabular}{|c|c|c|c|c|c|c|c|c|c|c|c|c|}
\hline \multicolumn{13}{|c|}{ Artificial water } \\
\hline \multirow{2}{*}{50} & $\mathrm{~S}$ & 6.2 & 3.6 & 19.00 & 0.29 & 7.55 & 7.2 & 4.24 & 24.20 & 5.60 & 6.99 & C4-S4 \\
\hline & $\mathrm{W}$ & 6.0 & 3.41 & 18.69 & 0.25 & 6.99 & 6.8 & 4.18 & 23.50 & 5.05 & 7.11 & C3-S4 \\
\hline \multirow{2}{*}{250} & $\mathrm{~S}$ & 6.1 & 3.6 & 19.00 & 0.25 & 8.33 & 9.4 & 3.98 & 23.50 & 9.50 & 6.38 & C4-S4 \\
\hline & $\mathrm{W}$ & 6.0 & 3.21 & 18.72 & 0.23 & 7.13 & 8.2 & 3.18 & 22.40 & 8.70 & 6.76 & C3-S4 \\
\hline \multirow{2}{*}{500} & $\mathrm{~S}$ & 6.7 & 4.0 & 19.20 & 0.34 & 9.29 & 9.9 & 3.23 & 25.80 & 9.70 & 6.21 & C4-S4 \\
\hline & $\mathrm{W}$ & 6.4 & 3.92 & 18.89 & 0.28 & 7.11 & 8.4 & 2.19 & 23.70 & 8.79 & 6.79 & C4-S4 \\
\hline \multirow{2}{*}{1000} & $\mathrm{~S}$ & 7.3 & 3.9 & 18.00 & 0.35 & 10.31 & 8.9 & 4.48 & 24.80 & 8.28 & 5.83 & C4-S4 \\
\hline & W & 7.1 & 3.81 & 17.01 & 0.29 & 9.21 & 8.5 & 3.51 & 23.71 & 7.79 & 5.71 & C4-S4 \\
\hline \multirow{2}{*}{1500} & $\mathrm{~S}$ & 6.4 & 3.8 & 20.43 & 0.36 & 7.25 & 7.5 & 4.78 & 23.36 & 7.40 & 7.51 & C4-S4 \\
\hline & W & 6.2 & 3.79 & 19.61 & 0.21 & 6.11 & 6.4 & 3.81 & 22.21 & 6.31 & 7.84 & C4-S4 \\
\hline \multirow{2}{*}{5000} & $\mathrm{~S}$ & 6.8 & 3.3 & 16.65 & 0.36 & 7.20 & 6.1 & 4.21 & 23.50 & 2.60 & 6.45 & C3-S4 \\
\hline & W & 6.5 & 3.49 & 15.42 & 0.29 & 6.36 & 5.9 & 3.41 & 22.53 & 2.30 & 6.22 & C3-S4 \\
\hline
\end{tabular}

*Refers to output of human uses; W: Winter; S: Summer; C1: Low salinity; C2: Medium salinity; C3: High salinity; C4: Very high salinity; S1: Low alkalinity; S2: Medium alkalinity; S3: High alkalinity; S4: Very high alkalinity; Epm: equivalents per million.
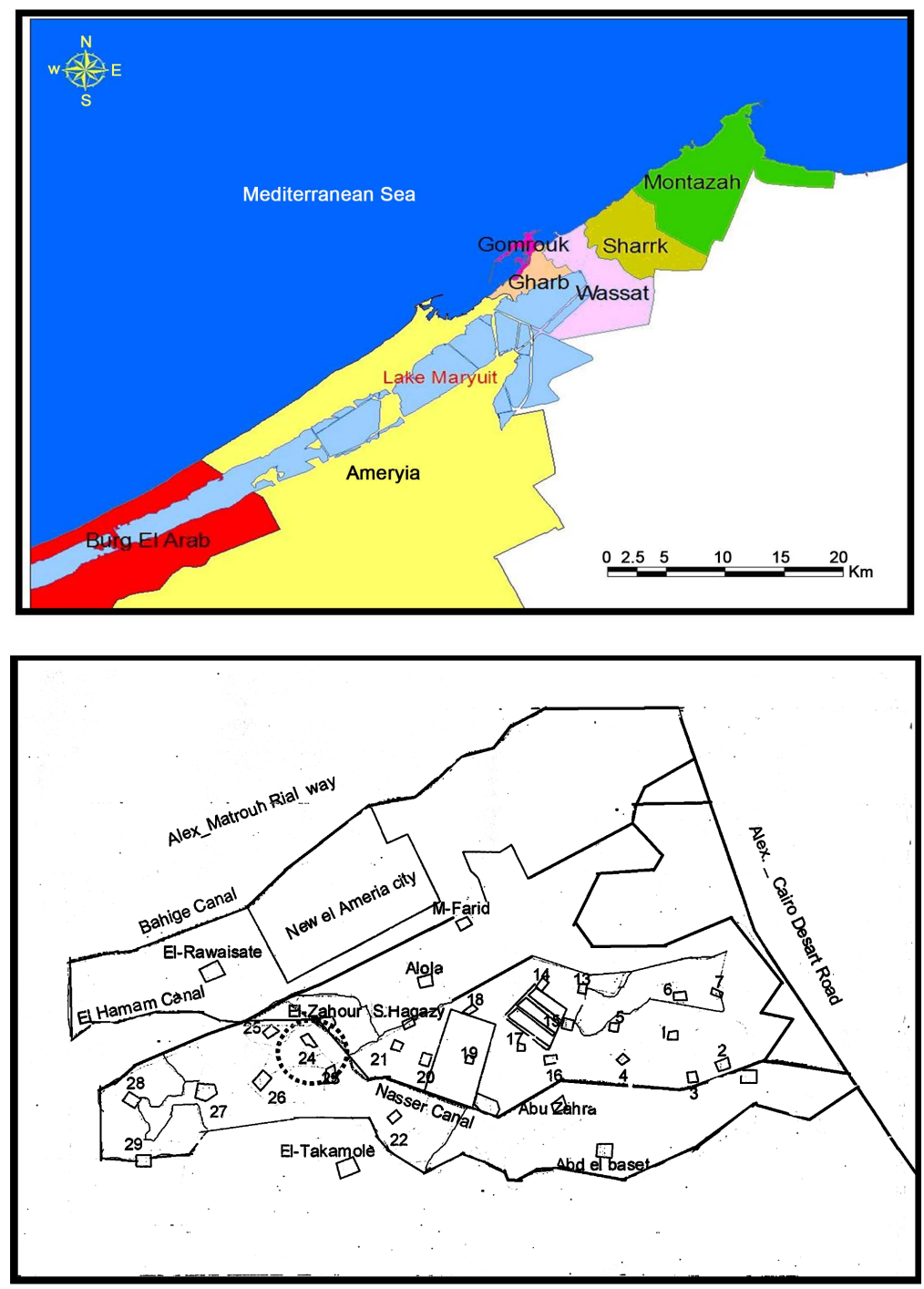

Figure 1. Location map of the study area. 
Mary Mina area. While some groundwater samples show increasing of calcium over magnesium $\left(\mathrm{Na}^{+}>\mathrm{Ca}^{2+}>\right.$ $\mathrm{Mg}^{2+}$ ) as a result of cation exchange processes

Chemical distribution of anions shows that bicarbonate is the most dominant anion followed by chloride and sulphate anions of the irrigated water sample of low salinity contents $\left(\mathrm{HCO}_{3}^{-}>\mathrm{Cl}^{-}>\mathrm{SO}_{4}^{2-}\right)$, bicarbonate concentration ranges from $171 \mathrm{mg} / \mathrm{L}$ to $177 \mathrm{ppm}$, chloride concentration ranges from $103 \mathrm{mg} / \mathrm{l}$ to $67 \mathrm{mg} / \mathrm{l}$, sulphate concentration ranges from 24 to $22 \mathrm{mg} / \mathrm{l}$ at Bahig (fresh water) area.

El-Rawaisate (artesian water), shows that chloride is the most dominant anion followed by bicarbonate and sulphate anions of the irrigated water sample of low salinity contents $\left(\mathrm{Cl}^{-}>\mathrm{HCO}_{3}^{-}>\mathrm{SO}_{4}^{2-}\right)$, chloride concentration ranges from $209 \mathrm{mg} / \mathrm{l}$ to $220 \mathrm{mg} / \mathrm{l}$, bicarbonate concentration ranges from $170 \mathrm{mg} / \mathrm{L}$ to $158 \mathrm{ppm}$ and sulphate concentration ranges from 116 to $117 \mathrm{mg} / \mathrm{l}$.

Mary Mina (sewage water), (artesian water), shows that bicarbonate is the most dominant anion followed by chloride and sulphate anions of the irrigated water sample of low salinity contents $\left(\mathrm{Cl}^{-}>\mathrm{SO}_{4}^{2-}>\mathrm{HCO}_{3}^{-}\right)$, chloride concentration ranges from $859 \mathrm{mg} / \mathrm{l}$ to $834 \mathrm{mg} / \mathrm{l}$, bicarbonate concentration ranges from 268 to 124 $\mathrm{mg} / \mathrm{L}$ and sulphate concentration ranges from 116 to $115 \mathrm{mg} / \mathrm{l}$

Burg-El-Arab Industrial Zone (artificial water), shows that bicarbonate is the most dominant anion followed by chloride and sulphate anions of the irrigated water sample of low salinity contents $\left(\mathrm{HCO}_{3}^{-}>\mathrm{Cl}^{-}>\mathrm{SO}_{4}^{2-}\right.$ ), bicarbonate concentration ranges from $360 \mathrm{mg} / \mathrm{L}$ to $378 \mathrm{mg} / \mathrm{L}$, chloride concentration ranges from $209 \mathrm{mg} / \mathrm{l}$ to $220 \mathrm{mg} / \mathrm{l}$, sulphate concentration ranges from 116 to $115 \mathrm{mg} / \mathrm{l}$.

\subsection{Geochemical Classification of Irrigation Water}

\section{Trilinear Diagram}

The main purpose of the trilinear diagram proposed by [12] is to show different water types in a particular area. The diamond-shaped field of this diagram consists of two equal triangular fields. Generally, water which appears in the upper triangle has secondary salinity properties, where $\left(\mathrm{SO}_{4}^{2-}+\mathrm{Cl}^{-}\right)$exceed $\left(\mathrm{Na}^{+}+\mathrm{K}^{+}\right)$and the characteristic water types are $\mathrm{Ca}$ and $\mathrm{Mg}$ chlorides and sulphates. On the other hand, those which appear in the lower triangle are considered to have primary alkalinity properties where $\left(\mathrm{CO}_{3}^{2-}+\mathrm{HCO}_{3}^{-}\right)$exceed $\left(\mathrm{Ca}^{2+}+\right.$ $\mathrm{Mg}^{2+}$ ), and the characteristic water types are Na and $\mathrm{K}$ carbonates and bicarbonates. Figure 2 shows two trilinear plots of major ions in water samples collected from the study area in summer 2011 and winter 2012.

-Bahig area (fresh water) and El-Rawaisate area (artesian) appear in the lower triangle are considered to have primary alkalinity properties where $\left(\mathrm{CO}_{3}^{2-}+\mathrm{HCO}_{3}^{-}\right)$exceed $\left(\mathrm{Ca}^{2+}+\mathrm{Mg}^{2+}\right)$, and the characteristic water types are $\mathrm{Na}$ and $\mathrm{K}$ carbonates and bicarbonates. While, Burg-El-Arab Industrial Zone (artificial water), Mary Mina (Sludge water) samples appear in the upper triangle of the diamond-shaped field, the dominant water types are $\mathbf{C a}$ and $\mathbf{M g}$ chlorides and sulphates. Water in these areas enriched in $\mathrm{Mg}^{2+}$ than water in the Bahig area (fresh water) and El-Rawaisate area (artesian)) indicating its precipitation from water as it moves downgradient. This process is responsible for the dominance of Mg-rich carbonate deposits and cement within the Quaternary clastic sediments of the study area. These deposits affect ground-water quality and may create perched conditions in some areas.

\subsection{Heavy Metals in Irrigation Water}

Generally,in Burg-El-Arab enriched with Fe, followed by Mn, Pb, Zn, Cu, Co, Ni, and Cd. [13] fond that the soluble heavy metals (ppm) in wastewater were as follows: Fe (34.0 and 56.0) > Mn (9.60 and 17.90) > Zn (5.70 and 6.80) $>\mathrm{Pb}(5.70$ and 4.30) $>\mathrm{Cu}(4.60$ and 3.90) $>\mathrm{Co}(2.50$ and 3.70) $>\mathrm{Ni}(2.50$ and 1.90).Concentration of $\mathrm{Fe}, \mathrm{Mn}, \mathrm{Zn}, \mathrm{Cu}, \mathrm{Pb}, \mathrm{Cd}$, $\mathrm{Co}$ and $\mathrm{Ni}$ in water samples from Burg -El-Arab canals (Table 2), revealed that the factories liquid wastes, sludge, artesian discharged in irrigation water.

The concentration of metals decreased by getting far away from the sources of pollution and could be arranged, descending between distance at $50 \mathrm{~m}$ (in summer 201) Nile water (Bahig canal) (control), as following: $\mathrm{Fe}(0.3$ [1] 1.23) > Mn (0.06 - 0.65) > Zn (0.08 - 0.52) > Cu (0.0 [1] 0.16) > Pb, Cd, Co, Ni. Generally the liquid wastes were enriched with these metals and were much higher than the maximum concentration recommended by [14] for waste water for irrigation. Also, levels of the heavy metals in water samples were generally higher than which are recorded for fresh water in several studies, since the reported values (ppm) were in the range of 0.11 - 0.77 for Fe, 0.01 - 0.11 for $\mathrm{Mn}, 0.01$ - 0.09 for $\mathrm{Zn}, 0.0$ [1] 0.12 for $\mathrm{Cu}, 0.01$ - 0.06 for $\mathrm{Pb}, 0.02$ - 0.04 for Cd, 0.0 [1] 0.06 for Coand $0.01-0.02$ for Ni [15]-[18]. Stated that the concentrations of heavy metals in unpol- 
Table 2. Heavy metals in irrigation water of samples collected at different distance from Bahig area (Nile water) and BURGEL ARAB area (Artesian, Sludge* and Artificial water).

\begin{tabular}{|c|c|c|c|c|c|c|c|c|c|}
\hline \multirow{2}{*}{$\begin{array}{l}\text { Distance } \\
\text { (Meter) }\end{array}$} & \multirow{2}{*}{ Seasons } & $\mathrm{Fe}$ & $\mathrm{Mn}$ & $\mathrm{Zn}$ & $\mathrm{Cu}$ & $\mathrm{Pb}$ & $\mathrm{Cd}$ & Co & $\mathrm{Ni}$ \\
\hline & & \multicolumn{8}{|c|}{ ppm (mg/L) } \\
\hline \multicolumn{10}{|c|}{ Nile water } \\
\hline \multirow{2}{*}{50} & $\mathrm{~S}$ & 1.23 & 0.65 & 0.52 & 0.16 & $\mathrm{Nd}$ & $\mathrm{Nd}$ & $\mathrm{Nd}$ & $\mathrm{Nd}$ \\
\hline & W & 1.23 & 0.71 & 0.52 & 0.16 & $\mathrm{Nd}$ & $\mathrm{Nd}$ & $\mathrm{Nd}$ & $\mathrm{Nd}$ \\
\hline \multirow{2}{*}{250} & S & 0.71 & 0.43 & 0.31 & 0.07 & $\mathrm{Nd}$ & $\mathrm{Nd}$ & $\mathrm{Nd}$ & $\mathrm{Nd}$ \\
\hline & W & 0.93 & 0.61 & 0.31 & 0.07 & $\mathrm{Nd}$ & $\mathrm{Nd}$ & $\mathrm{Nd}$ & $\mathrm{Nd}$ \\
\hline \multirow{2}{*}{500} & S & 0.62 & 0.25 & 0.21 & 0.09 & $\mathrm{Nd}$ & $\mathrm{Nd}$ & $\mathrm{Nd}$ & Nd \\
\hline & W & 0.73 & 0.26 & 0.21 & 0.09 & $\mathrm{Nd}$ & $\mathrm{Nd}$ & $\mathrm{Nd}$ & $\mathrm{Nd}$ \\
\hline \multirow{2}{*}{1000} & $\mathrm{~S}$ & 0.58 & 0.07 & 0.06 & 0.07 & $\mathrm{Nd}$ & $\mathrm{Nd}$ & $\mathrm{Nd}$ & $\mathrm{Nd}$ \\
\hline & W & 0.71 & 0.02 & 0.06 & 0.07 & $\mathrm{Nd}$ & $\mathrm{Nd}$ & $\mathrm{Nd}$ & $\mathrm{Nd}$ \\
\hline \multirow{2}{*}{1500} & S & 0.44 & 0.09 & 0.05 & 0.02 & $\mathrm{Nd}$ & $\mathrm{Nd}$ & $\mathrm{Nd}$ & $\mathrm{Nd}$ \\
\hline & W & 0.61 & 0.01 & 0.05 & 0.02 & $\mathrm{Nd}$ & $\mathrm{Nd}$ & $\mathrm{Nd}$ & $\mathrm{Nd}$ \\
\hline \multirow{2}{*}{5000} & $\mathrm{~S}$ & 0.31 & 0.06 & 0.08 & 0.01 & $\mathrm{Nd}$ & $\mathrm{Nd}$ & $\mathrm{Nd}$ & $\mathrm{Nd}$ \\
\hline & W & 0.21 & 0.01 & 0.08 & 0.01 & $\mathrm{Nd}$ & $\mathrm{Nd}$ & $\mathrm{Nd}$ & $\mathrm{Nd}$ \\
\hline \multicolumn{10}{|c|}{ Artesia } \\
\hline \multirow{2}{*}{50} & $\mathrm{~S}$ & 2.81 & 0.95 & 0.90 & 0.31 & $\mathrm{Nd}$ & $\mathrm{Nd}$ & $\mathrm{Nd}$ & $\mathrm{Nd}$ \\
\hline & W & 2.82 & 0.91 & 1.0 & 0.35 & $\mathrm{Nd}$ & $\mathrm{Nd}$ & $\mathrm{Nd}$ & $\mathrm{Nd}$ \\
\hline \multirow{2}{*}{250} & S & 0.91 & 0.58 & 0.20 & 0.21 & $\mathrm{Nd}$ & $\mathrm{Nd}$ & $\mathrm{Nd}$ & $\mathrm{Nd}$ \\
\hline & $\mathrm{W}$ & 1.66 & 0.81 & 0.26 & 0.24 & $\mathrm{Nd}$ & $\mathrm{Nd}$ & $\mathrm{Nd}$ & $\mathrm{Nd}$ \\
\hline \multirow{2}{*}{500} & $\mathrm{~S}$ & 0.82 & 0.35 & 0.16 & 0.11 & $\mathrm{Nd}$ & $\mathrm{Nd}$ & $\mathrm{Nd}$ & $\mathrm{Nd}$ \\
\hline & W & 0.93 & 0.36 & 0.17 & 0.16 & $\mathrm{Nd}$ & $\mathrm{Nd}$ & $\mathrm{Nd}$ & $\mathrm{Nd}$ \\
\hline \multirow{2}{*}{1000} & $\mathrm{~S}$ & 0.78 & 0.17 & 0.90 & $\mathrm{Nd}$ & $\mathrm{Nd}$ & $\mathrm{Nd}$ & $\mathrm{Nd}$ & $\mathrm{Nd}$ \\
\hline & W & 0.81 & 0.12 & $\mathrm{Nd}$ & $\mathrm{Nd}$ & $\mathrm{Nd}$ & $\mathrm{Nd}$ & $\mathrm{Nd}$ & $\mathrm{Nd}$ \\
\hline \multirow{2}{*}{1500} & S & 0.74 & 0.09 & 0.7 & $\mathrm{Nd}$ & $\mathrm{Nd}$ & $\mathrm{Nd}$ & $\mathrm{Nd}$ & $\mathrm{Nd}$ \\
\hline & W & 0.91 & 0.8 & $\mathrm{Nd}$ & $\mathrm{Nd}$ & $\mathrm{Nd}$ & $\mathrm{Nd}$ & $\mathrm{Nd}$ & $\mathrm{Nd}$ \\
\hline \multirow{2}{*}{5000} & $\mathrm{~S}$ & 0.17 & 0.06 & $\mathrm{Nd}$ & $\mathrm{Nd}$ & $\mathrm{Nd}$ & $\mathrm{Nd}$ & $\mathrm{Nd}$ & $\mathrm{Nd}$ \\
\hline & W & 0.21 & 0.06 & $\mathrm{Nd}$ & $\mathrm{Nd}$ & $\mathrm{Nd}$ & $\mathrm{Nd}$ & $\mathrm{Nd}$ & $\mathrm{Nd}$ \\
\hline \multicolumn{10}{|c|}{ Sludge water ${ }^{*}$} \\
\hline \multirow{2}{*}{50} & $\mathrm{~S}$ & 3.69 & 1.32 & 1.15 & 0.64 & 0.62 & 0.46 & 0.3 & 0.82 \\
\hline & W & 3.77 & 1.36 & 1.19 & 0.68 & 0.66 & 0.61 & 1.20 & 0.92 \\
\hline \multirow{2}{*}{250} & $\mathrm{~S}$ & 1.81 & 0.68 & 0.49 & 0.38 & 0.34 & 0.30 & 0.22 & 0.47 \\
\hline & W & 1.86 & 0.71 & 0.49 & 0.41 & 0.39 & 0.34 & 0.32 & 0.28 \\
\hline \multirow{2}{*}{500} & $\mathrm{~S}$ & 1.31 & 0.45 & 0.33 & 0.27 & 0.26 & 0.24 & 0.15 & 0.47 \\
\hline & W & 1.36 & 0.46 & 0.34 & 0.32 & 0.27 & 0.26 & 0.27 & 0.50 \\
\hline \multirow{2}{*}{1000} & $\mathrm{~S}$ & 1.17 & 0.27 & 0.23 & 0.07 & 0.17 & 0.14 & 0.10 & 0.47 \\
\hline & W & 1.13 & 0.32 & 0.23 & 0.12 & 0.21 & 0.16 & 0.17 & 0.32 \\
\hline 1500 & $\mathrm{~S}$ & 0.83 & 0.17 & 0.16 & 0.08 & 0.16 & 0.08 & 0.04 & 0.32 \\
\hline & W & 0.91 & 0.18 & 0.16 & 0.09 & 0.23 & 0.09 & 0.19 & 0.10 \\
\hline 5000 & $S$ & 0.17 & 0.09 & 0.08 & 0.04 & 0.04 & 0.3 & .0 .01 & 0.09 \\
\hline 5000 & W & 0.21 & 0.09 & 0.10 & 0.05 & 0.04 & 0.06 & 0.06 & 0.06 \\
\hline & & & ial wa & & & & & & \\
\hline 50 & $\mathrm{~S}$ & 7.38 & 2.63 & 2.29 & 1.28 & 1.24 & 0.91 & 0.54 & 1.56 \\
\hline & $\mathrm{W}$ & 7.53 & 2.72 & 2.38 & 1.36 & 1.32 & 1.21 & 0.95 & 1.68 \\
\hline
\end{tabular}




\section{Continued}

\begin{tabular}{cccccccccc}
\hline 250 & S & 3.61 & 1.35 & 0.97 & 0.75 & 0.68 & 0.59 & 0.44 & 1.09 \\
& W & 3.72 & 1.42 & 0.98 & 0.81 & 0.78 & 0.68 & 0.61 & 0.95 \\
500 & S & 2.61 & 0.90 & 0.66 & 0.53 & 0.51 & 0.48 & 0.29 & 0.90 \\
& $\mathrm{~W}$ & 2.72 & 0.92 & 0.67 & 0.64 & 0.54 & 0.52 & 0.49 & 0.95 \\
\multirow{3}{*}{1000} & $\mathrm{~S}$ & 2.15 & 0.53 & 0.45 & 0.31 & 0.33 & 0.27 & 0.18 & 0.59 \\
& $\mathrm{~W}$ & 2.26 & 0.64 & 0.46 & 0.23 & 0.42 & 0.31 & 0.31 & 0.61 \\
\multirow{2}{*}{1500} & $\mathrm{~S}$ & 1.60 & 0.33 & 0.31 & 0.16 & 0.23 & 0.15 & 0.07 & 0.17 \\
& $\mathrm{~W}$ & 1.89 & 0.35 & 0.32 & 0.18 & 0.45 & 0.18 & 0.19 & 0.19 \\
5000 & $\mathrm{~S}$ & 0.35 & 0.17 & 0.15 & 0.08 & 0.07 & 0.06 & 0.06 & 0.09 \\
& $\mathrm{~W}$ & 0.37 & 0.18 & 0.19 & 0.09 & 0.08 & 0.12 & 0.09 & 0.12 \\
R. g for water irrigation agriculture (FOW,1985) & 5.0 & 0.30 & 2.0 & 0.2 & - & 5.0 & 0.05 & 0.20 \\
& & 0.146 & 0.102 & 0.056 & 0.41 & 0.07 & 0.04 & 0.02 & 0.01 \\
\hline
\end{tabular}

S: summer; W: winter; ppm: part per million.
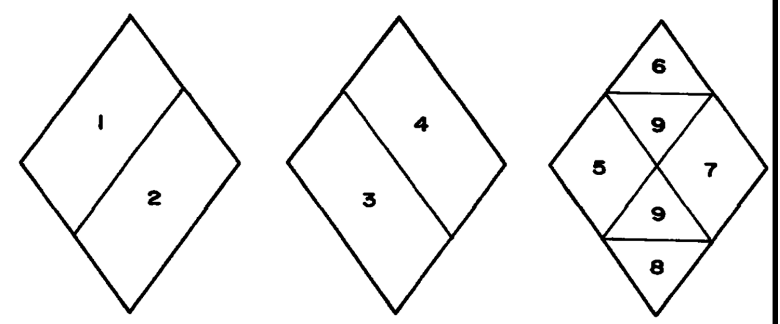

Fig. 2. Water types on a trilinear diagram:

area $1-\left(\mathrm{Ca}^{+2}+\mathrm{Mg}^{+2}\right)>\left(\mathrm{Na}^{+}+\mathrm{K}^{+}\right)$;

area $2-\left(\mathrm{Ca}^{+2}+\mathrm{Mg}^{+2}\right)<\left(\mathrm{Na}^{+}+\mathrm{K}^{+}\right)$;

area $3-\left(\mathrm{HCO}_{3}^{-}+\mathrm{CO}_{3}^{-2}\right)>\left(\mathrm{Cl}^{-}+\mathrm{SO}_{4}^{-2}\right)$;

area $4-\left(\mathrm{HCO}_{3}^{-}+\mathrm{CO}_{3}^{-2}\right)<\left(\mathrm{Cl}^{-}+\mathrm{SO}_{4}^{-2}\right)$.

area 5 - carbonate hardness (secondary alkalinity) $>50 \%$;

area 6 - noncarbonate hardness (secondary salinity) $>50 \%$ :

area 7 - noncarbonate alkali (primary salinity) $>50 \%$;

area 8 - carbonate alkali (primary alkalinity) $>\mathbf{5 0 \%}$;

area 9 - no dominant cation-anion pair.

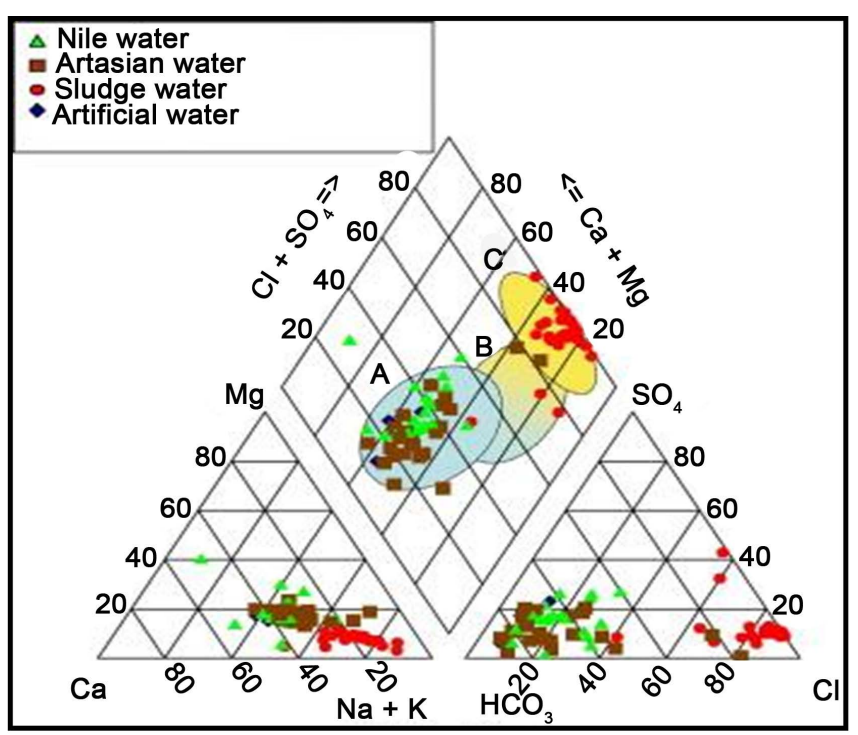

Figure 2. Piper's trilinear diagram. 
luted Nile water were as follow in ppm :Fe $0.77>$ Mn $0.11>$ Zn $0.09>$ Cu0.01 and Pb 0.01. Also, concentrations of heavy metals (ppm) in industrial wastewater were as follow: Fe $34.40>\mathrm{Pb} 3.80>\mathrm{Mn} 2.50>$ Co $1.50>$ Zn $0.69>$ Cu 0.47 Table 2 .

[19] found that the superphosphate fertilizer contained varying amounts of heavy metals particularly $\mathrm{Cd}$, Pb and $\mathrm{Ni}$ and these concentrations (ug/g) were $23.1 \mathrm{Cd}, 35.0 \mathrm{~Pb}$ and $60.0 \mathrm{Ni}$ Table 2.

Superphosphate, pesticides, sludge, brick factories were the main sources of pollution by heavy metals such as Fe, Mn, Zn, Cu, Pb, Cd, Co and Ni [16] [20]-[23].

\section{4. $\mathrm{BOD}_{5}$ and Turbidity in Irrigation Water}

[8] [9] found that BOD (biochemical oxygen demand) this test measures the oxygen required by microorganisms during the degradation of water sample increasing by increasing in sewage sludge In summer July 2011 (50 m $5000 \mathrm{~m}$ ) the Turbidity in Industrial water (1286 TU-1246 TU) and domestic wastes (1487 TU - 1446 TU) contribute with both inorganic and organic materials Table 3. Practically, all public water supplies are free from noticeable turbidity [10] and [11]. It is the clear from the present study the waste water irrigated decreased with treatment the artificial water before mixed with Nile water and the same with the sludge water collected in Mary mina station from Tokyo Tech and used Cetro-cal compound from Agrico.co reduced salinity and heavy metals content in artesian water.

[2] elevated levels of metals in water may be toxic they enter the food chain and could be harmful to animal and human being.

\subsection{Assessment of the Environmental Impacts Resulting from Irrigation by Different Types of Water on Soil and Planting:}

Irrigation water in the study area including Burg-El-Arab (Industrial water), Mary Mina (sewage water) , Bahig (fresh water) and El-Rawaisate (artesian water). According to U.S Salinity Laboratory [24] based on the Sodium Adsorption Ratio (SAR), and the specific conductance. Generally, irrigation water with low SAR is much desirable. The suitability of groundwater for agricultural purposes depends on the effect of mineral constituents of water on both plants and soil. Effects of salts on soils causing changes in soil structure, permeability and aeration indirectly affect plant growth. [25] and US Salinity Laboratory [24] proposed irrigational specifications for evaluating the suitability of water for irrigation use. There is a significant relationship between sodium adsorption ratio (SAR) values for irrigation water and the extent to which sodium is adsorbed by the soils. If water used for irrigation is high in sodium and low in calcium, the cation exchange complex may become saturated with sodium, which can destroy the soil structure owing to dispersion of clay particles [26]. SAR was computed using the equation given below [27]

$$
S A R=\frac{\mathrm{Na}}{\sqrt{(\mathrm{Ca}+\mathrm{Mg}) / 2}}
$$

where, the concentration of these cations is expressed in e.p.m. According to the U.S. Salinity Laboratory diagram, the water is divided into classes C1, C2, C3, and C4, which denote the conductance and S1, S2, S3, and S4, which denote SAR (table). The recommended classification of water for irrigation according to SAR ranges are shown in Table 4. If the SAR value is greater than $6-9$, the irrigation water will cause permeability problems on shrinking and swelling of clayey soils types [28].

As shown from Figure 3 as well as Table 4, and according to the foregoing discussion, it clears that:

-Nile water samples falls in the good water class (C2-S1, S2) where C2 reflects good water for soil of medium permeability for most plants, and S1, S2 reflect good for coarse grained permeability soils, unsatisfactory for highly clayey soil with low leaching.

-Artesian water falls in the moderate water class (C3-S3) where medium to highly saline water and highly sodium content. C3 reflects satisfactory for plants, having a moderate salts tolerance on soils of moderate permeability with leaching, S3 means suitable only with good drainage, high leaching and organic matter addition some chemical additives.

-Sludge water and artificial water fall in the bad water class C4-S4, where C4 reflects highly saline water, having satisfactory for salt tolerant crops on soils of good permeability with special leaching. S4 reflects very highly sodium and unsatisfactory. 
Table 3. BOD and Total Suspended Mater in irrigation water of samples collected at different distance from BAHIG area (Nile water) and BURG-EL ARAB area (Artesian, Sludge* and Artificial water).

\begin{tabular}{|c|c|c|c|}
\hline Distance (m) & Seasons & BOD mg/L & Total suspended mater TU (mg/L) \\
\hline \multicolumn{4}{|c|}{ Nile water } \\
\hline \multirow[b]{2}{*}{50} & S & 7.5 & 151 \\
\hline & W & 7.2 & 149 \\
\hline \multirow[b]{2}{*}{250} & $S$ & 7.6 & 149 \\
\hline & W & 7.3 & 146 \\
\hline \multirow{2}{*}{500} & S & 7.6 & 152 \\
\hline & W & 7.4 & 150 \\
\hline \multirow{2}{*}{1000} & S & 7.6 & 152 \\
\hline & W & 7.3 & 148 \\
\hline \multirow{2}{*}{1500} & S & 7.5 & 150 \\
\hline & W & 7.2 & 147 \\
\hline \multirow{2}{*}{5000} & S & 7.8 & 153 \\
\hline & $\mathrm{W}$ & 7.3 & 148 \\
\hline \multicolumn{4}{|c|}{ Artesian water } \\
\hline \multirow{2}{*}{50} & S & 6.5 & 142 \\
\hline & $\mathrm{W}$ & 6.1 & 140 \\
\hline \multirow{2}{*}{250} & S & 6.5 & 150 \\
\hline & $\mathrm{W}$ & 6.1 & 147 \\
\hline \multirow{3}{*}{500} & S & 6.4 & 145 \\
\hline & & & \\
\hline & W & 6.2 & 143 \\
\hline \multirow{2}{*}{1000} & S & 6.5 & 142 \\
\hline & $\mathrm{W}$ & 6.2 & 140 \\
\hline \multirow{2}{*}{1500} & S & 6.5 & 152 \\
\hline & $\mathrm{W}$ & 6.3 & 146 \\
\hline \multirow{2}{*}{5000} & S & 6.8 & 146 \\
\hline & $\mathrm{W}$ & 6.5 & 142 \\
\hline \multicolumn{4}{|c|}{ Sludge water ${ }^{*}$} \\
\hline \multirow[b]{2}{*}{50} & S & 563.7 & 1487 \\
\hline & W & 561.2 & 1482 \\
\hline \multirow{2}{*}{250} & S & 546.5 & 1483 \\
\hline & W & 542.2 & 1480 \\
\hline
\end{tabular}




\section{Continued}

\begin{tabular}{|c|c|c|c|}
\hline \multirow{2}{*}{500} & $\mathrm{~S}$ & 463.3 & 1389 \\
\hline & W & 461.2 & 1386 \\
\hline \multirow{2}{*}{1000} & S & 578.3 & 1487 \\
\hline & W & 576.1 & 1485 \\
\hline \multirow{2}{*}{1500} & S & 563.2 & 1453 \\
\hline & W & 560.1 & 1450 \\
\hline \multirow{3}{*}{5000} & S & 563.8 & 1446 \\
\hline & & 562.4 & 1442 \\
\hline & & Artificial wa & \\
\hline \multirow{2}{*}{50} & S & 283.4 & 1286 \\
\hline & W & 280.2 & 1284 \\
\hline \multirow{2}{*}{250} & S & 279.8 & 1278 \\
\hline & W & 276.3 & 1273 \\
\hline \multirow{2}{*}{500} & $S$ & 299.8 & 1280 \\
\hline & W & 296.5 & 1276 \\
\hline \multirow{2}{*}{1000} & S & 264.2 & 1269 \\
\hline & W & 262.1 & 1263 \\
\hline \multirow{2}{*}{1500} & S & 246.3 & 1285 \\
\hline & W & 242.1 & 1282 \\
\hline \multirow{2}{*}{5000} & S & 268.8 & 1246 \\
\hline & W & 265.6 & 1243 \\
\hline
\end{tabular}

S: summer; W: winter; mg/L: milligrams per liter; TU: turbidity.

\section{Table 4. Classification and description of conductivity and sodium.}

\begin{tabular}{|c|c|c|}
\hline $\mathrm{C}$ & Degree & Description \\
\hline C1 & Low salinity water & Good \\
\hline C2 & Moderate to saline water & Good for soil of medium permeability for most plants. \\
\hline C3 & Medium to highly saline water & $\begin{array}{l}\text { Satisfactory for plants, having a moderate salts tolerance } \\
\text { on soils of moderate permeability with leaching. }\end{array}$ \\
\hline C4 & Highly saline water & Satisfactory for salt tolerant crops on soils of good permeability with special leaching. \\
\hline S & Degree & Description \\
\hline S1 & Low sodium water & Good \\
\hline $\mathrm{S} 2$ & Medium sodium water & $\begin{array}{l}\text { Good for coarse grained permeability soils, unsatisfactory for } \\
\text { highly clayey soil with low leaching. }\end{array}$ \\
\hline S3 & Highly sodium water & $\begin{array}{l}\text { Suitable only with good drainage, high leaching and organic } \\
\text { matter addition some chemical additives. }\end{array}$ \\
\hline S4 & Very highly sodium & Unsatisfactory. \\
\hline
\end{tabular}




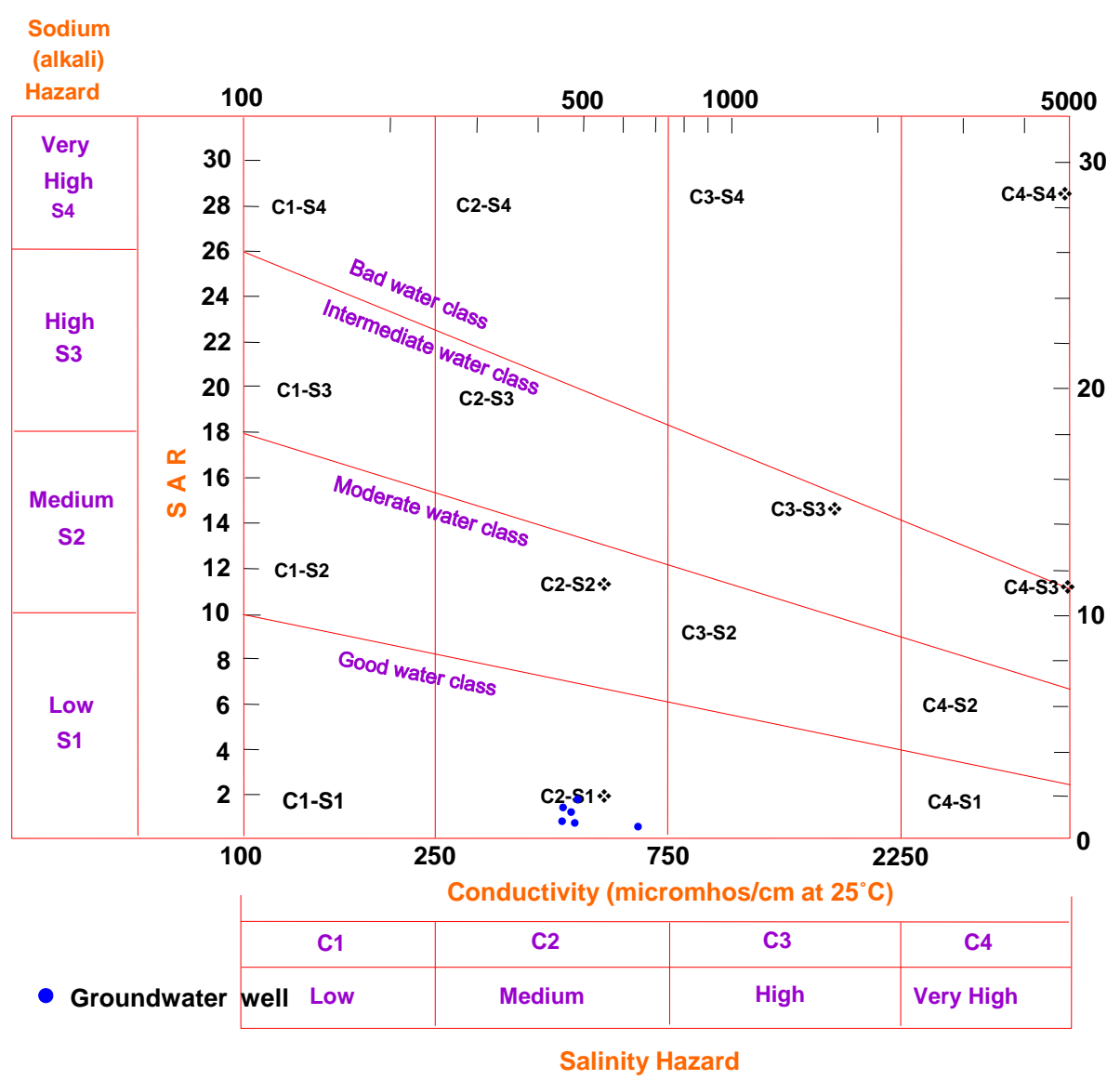

Figure 3. US salinity diagram for classification of irrigation waters summer season.

The non desirable effects resulting from irrigate by Sludge water and artificial water leading to excess concentration of sodium in irrigation water, where sodium ions tend to be absorbed by clay particles, displacing $\mathrm{Mg}$ and $\mathrm{Ca}$ ions. This exchange process of $\mathrm{Na}$ in water for $\mathrm{Ca}$ and $\mathrm{Mg}$ in soil reduces the permeability and eventually results in soil with poor internal drainage. Hence, air and water circulation is restricted during wet conditions and such soils are usually hard when dry. The irrigation water will cause permeability problems on shrinking and swelling of clayey soils types [28]-[31].

\section{Conclusion and Recommendation}

Obtained result indicated that samples of water of 2011 summer and winter of 2012 being at the least indicating that a pronounced accumulation of heavy metals were established. Those concentrations, however, had decreased by avoiding the pollution source; where samples collected at $5000 \mathrm{~m}$ from the source contained the lowest of heavy metals concentration. The results displayed that heavy metals contents in samples at $50 \mathrm{~m}$ distant from the sources of pollution exceeded that of the control $5000 \mathrm{~m}$ by about 30 to 35 time in irrigation water which used for grown plants in 5000 fedden. Generally, this work may express a vital point in heavy metals accumulation in the environment specially water system.

\section{References}

[1] Berrow, M.L and Reeves, G.A. (1984) Background Levels of Trace Elements in Soil and Water. International Conference, London.

[2] CAST (Council for Agricultural and Technology) (1976) Application of Sewage Sludge to Cropland; Appraisal of Potential Hazards of the Heavy Metals to Plants and Animals. Report No. 64. Coun. For Agric. Sci. and Tech., Ames, Iowa, 63 p. 
[3] Belkhiri, L., Boudoukha, A., Mouni, L. and Baouz, T. (2010) Application of Multivariate Statistical Methods and Inverse Geochemical Modeling for Characterization of Groundwater-A Case Study: Ain Azel Plain (Algeria). Geoderma, 159, 390-398. http://dx.doi.org/10.1016/j.geoderma.2010.08.016

[4] Abdel-Tawab, M.M. (1985) Soil Pollution as Effected by Some Industrial Waste at Helwan. El-Saff area. M.Sc. Thesis, Faculty of Agriculture, Cairo University, Giza.

[5] APHA (American Public Health Association) (1992) Stander Methods of Examination of Water and Waste Water. 18th Edition, American Public Health Association, Washington DC.

[6] Jackson, M.L. (1973) Soil Chemical Analysis. Advanced Course Ed. 2. A Manual of Methods Useful for Instruction and Research in Soil Chemistry, Physical Chemistry of Soils, Soil Fertility and Genesis Revised from Original Edition of 1965.

[7] Page, A.L., Miller, R.H. and Keeney (1982) Method of Soil Analysis. Part 2, ASA, SSSA, Madison.

[8] Mitchell, R. (1972) Water Pollution Microbiology. Wiley-Interscience, New York.

[9] Geradi, M.H. (1982) BOD Analysis: A Brief Review. Water Poll Control Association, PA Mag, 12.

[10] Sawyer, C.N. and McCarty, P.L. (1967) Chemistry for Sanitary Engineers. McGraw-Hill Book Co., New York.

[11] Holden, W.S. (1970) Water Treatment and Examination. Churchill, London.

[12] Piper, A.M. (1953) A Graphic Procedure in the Geochemical Interpretation of Water Analyses. Transactions, American Geophysical Union, 25, 914-928.

[13] Shalaby, M.H., Gobran, O.A. and Raslan, M.I. (1996) Chemical Properties of Soils as Affected by Pollution of Different Wastes. Egyptian Journal of Soil Science, 36, 23.

[14] FAO (1985) Water Quality for Agriculture, Irrigation Drainage. FAO, Roma.

[15] Eissa, A.M. and El-Kassas, H.I. (1999) Impact of Heavy Metals on Soil, Plant and Water at Abou-Zaable Area. Egyptian Journal of Soil Science, 9, 351.

[16] Ahmed, S.M. (2001) Phytoremidiation of Some Contaminated Water with Heavy Metals in the Kafer El-Dawar Industrial Area. Ph.D. Thesis, Faculty of Agriculture, University of Alexandria, Alexandria.

[17] Abou El-Naga, S.A., El-Shinnawi, M.S., El-Swaby, M.S. and Salem, A.A. (1996) Changes in Elemental Constituents of Soil and Plants under Irrigation with Wastewater. Menofiya Journal of Agricultural Research, 21, 1575.

[18] Ramadan, M.A. (1995) Studied on the Pollution of Agricultural Environment in Egypt. Ph.D. Thesis, Faculty of Agriculture, Cairo University, Cairo.

[19] Peeezzarossa, B., Lubranal, Petruzzelli, G. and Toognoni (1991) The Effect of Cd Contents on Tomato Plants. Water, Air, \& Soil Pollution, 57, 589.

[20] Peeezzarossa, B., Petruzzelli, G., Matorgio, F. and Tognoni (1993) Effect of Reported Phosphate Fertilization on Heavy Metals Accumulation in Soil and Plants under Protected Cultivation. Communications in Soil Science and Plant Analysis, 24, 8.

[21] El-Sebaey, M.M. (1995) Studied on Chemical Pollution of Deferent Waters with Some Heavy Metals in Fayoum Governorate. Master's Thesis, Faculty of Agriculture at Moshtohor, Zagazig University, Zagazig.

[22] Omran, M.S., Fayiad, M.N. and El-Shikha, S.H. (1996) Effect of Industrial Activities on Pollution of Egyptian Soils. Proceeding of 6th International Conference on "Environmental Protection Is a Must", Alexandria, 21-23 May 1996, 658671.

[23] USDA (1997) Development of Phosphate Resource. In: Final Environmental Impact Statement, S.E. Ldohoi, 40 p.

[24] WHO (2006) Guidelines for Drinking-Water Quality. Recommendations, Volume 1, 3rd Edition, World Health Organization, Geneva.

[25] Wicklander, L. (1964) Chapter 4: Cation and Anion Phenomena. In: Bear, F.E., Ed., Chemistry of the Soil, Reinhold Publishing Co. PVT. LTD., New Delhi, 163-205.

[26] Singh, S. and Kumar, M. (2006) Heavy Metal Load of Soil, Water and Vegetables in Peri-Urban Delhi. Environmental Monitoring and Assessment, 120, 79-91. http://dx.doi.org/10.1007/s10661-005-9050-3

[27] Richards, R.L., Ed. (1954) Diagnosis and Improvement of Saline and Alkali Soils. Agriculture Hand Book No. 60, US Government Printing Office, Washington DC.

[28] Saleh, A., Al-Ruwih, F. and Shehata, M. (1999) Hydrogeochemical Processes Operating within the Main Aquifers of Kuwait. Journal of Arid Environments, 42, 195-209. http://dx.doi.org/10.1006/jare.1999.0511

[29] Collins, R. and Jenkins, A. (1996) The Impact of Agricultural Land Use on Stream Chemistry in the Middle Hills of the Himalayas, Nepal. Journal of Hydrology, 185, 71-86. http://dx.doi.org/10.1016/0022-1694(95)03008-5

[30] Scott, C.A., Faruqui, N.I. and Raschid-Sally, L. (2004) Wastewater Use in Irrigated Agriculture: Confronting the Live- 
lihood and Environmental Realities. CABI Publishing, Wallingford. http://dx.doi.org/10.1079/9780851998237.0000

[31] Seckler, D., Amarasinghe, U., Molden, D., de Silva, R. and Barker, R. (1998) World Water Demand and Supply, 1990 to 2025: Scenarios and Issues. Research Report 19. International Water Management Institute, Colombo. 
Scientific Research Publishing (SCIRP) is one of the largest Open Access journal publishers. It is currently publishing more than 200 open access, online, peer-reviewed journals covering a wide range of academic disciplines. SCIRP serves the worldwide academic communities and contributes to the progress and application of science with its publication.

Other selected journals from SCIRP are listed as below. Submit your manuscript to us via either submit@scirp.org or Online Submission Portal.
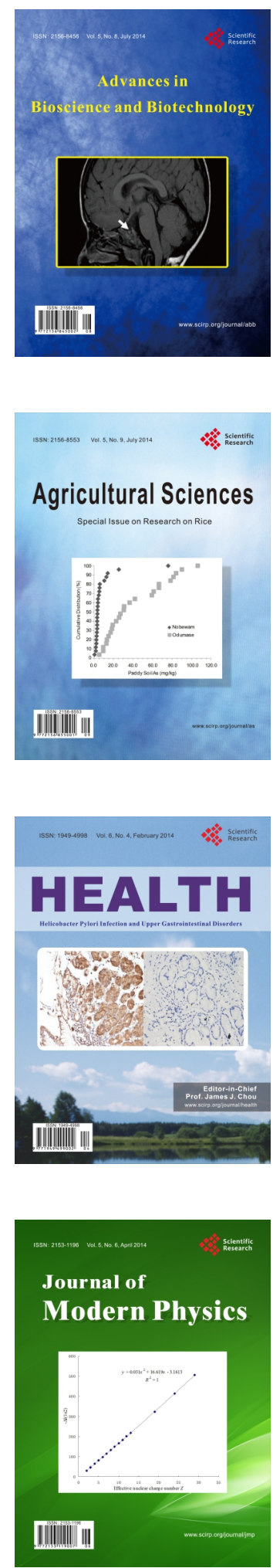
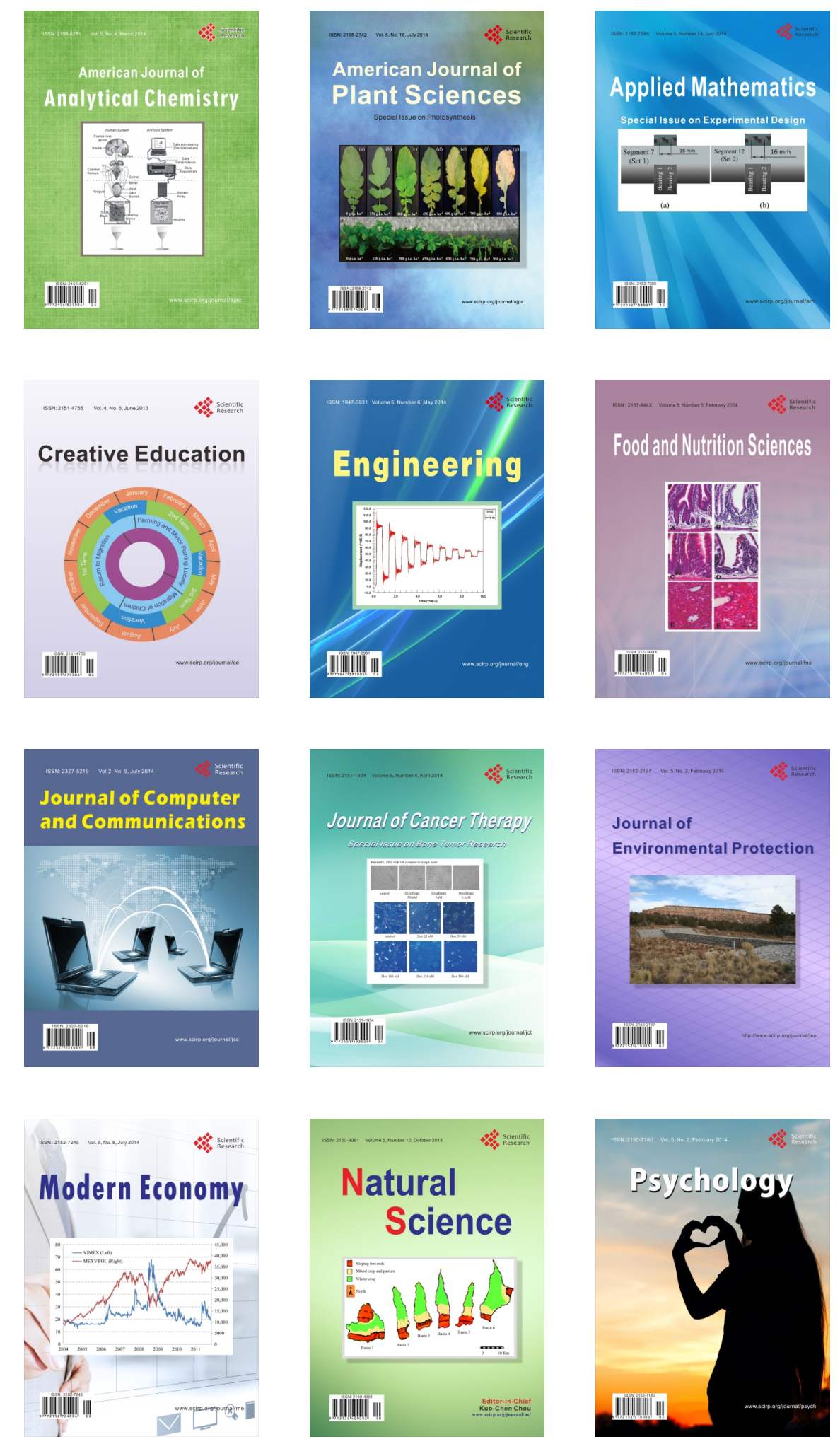